ISSN : $2302-1590$

E-ISSN: $2460-190 \mathrm{X}$

ECONOMICA

Journal of Economic and Economic Education Vol.4 No.2 (192-209)

\title{
ANALISIS PENGARUH PAD, DAU DAN DAK TERHADAP KEMISKINAN PADA KABUPATEN/KOTA DI PROVINSI SUMATERA BARAT DENGAN PERTUMBUHAN EKONOMI SEBAGAI VARIABEL INTERVENING
}

\author{
Jolianis \\ Dosen Program Studi Pendidikan Ekonomi STKIP- PGRI Sumbar \\ Jl. Gunung Pangilun No.1, Padang Sumatera Barat \\ Email : jolianiskoto@ymail.com
}

Submitted: 2016.06.21 Reviewed:2016.06.30Accepted: 2016.06.30

http://dx.doi.org/10.22202/economica.2016.v4.i2.633

\begin{abstract}
The purpose of this study is to investigate and analyze: 1) The influence of the PAD to economic growth, 2) Effect of $D A U$ to economic growth. 3) Effect of DAK to economic growth, 4) Effect of PAD against poverty, 5) Effect of DAU against poverty. 6) Effect of DAK against poverty, 7) The effect of economic growth on poverty, 8) Effect of PAD against poverty through economic growth as an intervening variable. 9) Effect of DAU against poverty through economic growth as an intervening variable, 10) Effect of DAK against poverty through economic growth as an intervening variable. This study uses secondary data over the last 5 years ie in 2010 - 2014. The study was conducted at the District /City in the province of West Sumatra totaling 19 regencies/cities in West Sumatra Province. The research found that: 1) PAD significant effect on economic growth. 2) DAU significant effect on economic growth. 3) DAK has no significant effect on economic growth. 4) PAD significant effect on poverty. 5) DAU significant effect on poverty. 6) DAK has no significant effect on poverty. 7) The economic growth significant effect on poverty. 8) Own-source revenue a significant effect on poverty through economic growth as an intervening variable. 9) DAU significant effect on poverty through economic growth as an intervening variable. 10) DAK has no significant effect on poverty through economic growth as an intervening variable
\end{abstract}

\begin{abstract}
Abstrak
Tujuan penelitian ini adalah untuk mengetahui dan menganalisis : 1) Pengaruh PAD terhadap pertumbuhan ekonomi, 2) Pengaruh DAU terhadap pertumbuhan ekonomi. 3) Pengaruh DAK terhadap pertumbuhan ekonomi, 4) Pengaruh PAD terhadap kemiskinan, 5) Pengaruh DAU terhadap kemiskinan. 6) Pengaruh DAK terhadap kemiskinan, 7) Pengaruh pertumbuhan ekonomi terhadap kemiskinan, 8) Pengaruh PAD terhadap kemiskinan melalui pertumbuhan ekonomi sebagai variabel intervening. 9) Pengaruh DAU terhadap kemiskinan melalui pertumbuhan ekonomi sebagai variabel intervening, 10) Pengaruh DAK terhadap kemiskinan melalui pertumbuhan ekonomi sebagai variabel intervening.Penelitian ini menggunakan data sekunder selama 5 tahun terakhir yaitu tahun 2010 - 2014. Penelitian ini dilakukan pada Pemerintah Kabupaten/Kota di Provinsi Sumatera Barat yang berjumlah 19 Kabupaten/Kota di Provinsi Sumatera Barat.Penelitian ini menemukan bahwa : 1) PAD berpengaruh signifikan terhadap pertumbuhan ekonomi. 2) DAU berpengaruh signifikan terhadap pertumbuhan ekonomi. 3) DAK tidak berpengaruh signifikan terhadap pertumbuhan ekonomi. 4) PAD berpengaruh signifikan terhadap kemiskinan. 5) DAU berpengaruh signifikan terhadap kemiskinan. 6) DAK tidak berpengaruh signifikan terhadap kemiskinan. 7) Pertumbuhan ekonomi berpengaruh signifikan terhadap kemiskinan. 8) Pendapatan asli daerah berpengaruh signifikan terhadap kemiskinan melalui pertumbuhan ekonomi sebagai variabel intervening. 9) DAU berpengaruh signifikan terhadap kemiskinan melalui pertumbuhan ekonomi sebagai variabel intervening. 10) DAK tidak berpengaruh signifikan terhadap kemiskinan melalui pertumbuhan ekonomi sebagai variabel intervening.
\end{abstract}

Keywords:PAD. DAU, DAK, Economic Growth and Poverty 


\section{PENDAHULUAN}

Penanggulangan kemiskinan menjadi perhatian utama pembangunan nasional dan daerah, terutama sejak diberlakukannya undang-undang tentang pemerintahan daerah. Hal tersebut seharusnya dijadikan momentum dan peluang untuk mewujudkan desentralisasi pembangunan yang sensitif terhadap persoalan lokal. Berarti memecahkan masalah kemiskinan secara tidak langsung memecahkan banyak persoalan sosial yang dihadapi oleh pemerintah daerah.

Dengan desentralisasi fiskal, pemerintah daerah kini memiliki kewenangan yang besar untuk merencanakan, merumuskan, dan melaksanakan kebijakan serta program pembangunan yang bisa disesuaikan dengan kebutuhan setempat. Oleh karena itu salah satu kunci yang harus diperhatikan dalam desentralisasi adalah bahwa pemerintah daerah harus lebih responsif terhadap kebutuhan penduduknya. Desentralisasi fiskal dalam pelaksanaannya masih mengalami berbagai kendala di daerah sehingga diperlukan evaluasi agar dapat mengetahui sejauhmana kebijakan desentralisasi fiskal mampu meningkatkan kesejahteraan masyarakat dan mengurangi kemiskinan pada suatu daerah.

Kemiskinan adalah sebuah kondisi ketidakmampuan seseorang dalam memenuhi kebutuhan dasar seperti makanan, pakaian, tempat berlindung, dan kesehatan. Adapun jumlah penduduk miskin di Sumatera Barat periode 2010 - 2015 adalah sebagai berikut :

\section{Tabel 1}

Jumlah Penduduk Muskin di Sumatera Barat

Periode 2010-2014

\begin{tabular}{cccc}
\hline No & Tahun & $\begin{array}{c}\text { Jumlah Penduduk Miskin } \\
\text { (dalam juta) }\end{array}$ & $\begin{array}{c}\text { Persentase } \\
\text { Perubahan }\end{array}$ \\
\hline 1 & 2010 & 429,30 & - \\
2 & 2011 & 430,02 & 0,17 \\
3 & 2012 & 442,09 & 2,81 \\
4 & 2013 & 404,74 & $(8,45)$ \\
5 & 2014 & 417,40 & 3.13 \\
\hline
\end{tabular}

Sumber : Sumbar Dalam Angka, 2015

Berdasarkan data pada tabel 1 terlihat bahwa jumlah penduduk miskin di Provinsi Sumtaera Barat mengalami peningkatan setiap tahunnya dengan angka yang berfluktuasi. Data ini memperlihatkan bahwa masih banyaknya jumlah penduduk yang berada dibawah garis kemiskinan di Provinsi Sumatatera Barat.

Dalam menelaah kebijakan pemerintah daerah dalam menanggulangi kemiskinan, perlu terlebih dahulu diperhatikan faktorfaktor penyebab kemiskinan atau dalam analisis kemiskinan disebut determinan kemiskinan. Kebijakan pemerintah daerah yang berorientasi pada program pengentasan kemiskinan sudah seharusnya didasarkan pada faktor-faktor yang mempengaruhi kondisi kemiskinan tersebut. Faktor-faktor penyebab kemiskinan dapat berupa karakteristik makro, sektor, komunitas, rumah tangga, dan individu (World Bank, 2002).
Dalam era otonomi daerah ditegaskan bahwa untuk pelaksanaan kewenangan Pemda (Pemerintah Daerah) maka Pempus (Pemerintah Pusat) akan mentransferkan dana perimbangan kepada Pemda. Dana Perimbangan tersebut terdiri dari Dana Alokasi Umum (DAU), Dana Alokasi Khusus (DAK), dan bagian daerah dari bagi hasil pajak pusat. Di samping itu, Pemerintah Daerah juga memiliki sumber pendanaan sendiri berupa PAD, pinjaman daerah, maupun lain-lain penerimaan daerah yang sah. Kebijakan penggunaan semua dana tersebut diserahkan kepada Pemda (Kuncoro, 2004).

Namun, pada praktiknya transfer dari pemerintah pusat merupakan sumber pendanaan utama Pemda untuk membiayai operasi utamanya sehari-hari, yang oleh Pemda "dilaporkan" diperhitungan APBD. Tujuan dari transfer ini adalah untuk 
mengurangi (kalau tidak mungkin menghilangkan) kesenjangan fiskal antar pemerintah dan menjamin tercapainya standar pelayanan publik minimum di seluruh negeri.

Pembangunan ekonomi daerah adalah suatu proses dimana pemerintah daerah dan seluruh komponen masyarakat mengelola berbagai sumber daya yang ada dan membentuk suatu pola kemitraan untuk menciptakan suatu lapangan pekerjaan baru dan merangsang perkembangan kegiatan ekonomi dalam daerah tersebut (Kuncoro, 2004). Terjadi pembangunan di suatu negara atau daerah ditandai dengan beberapa aktivitas perekonomian seperti meningkatnya produktivitas dan meningkatnya pendapatan perkapita sehingga terjadi perbaikan tingkat kesejahteraan.

Perbedaan PAD, DAU, DAK yang berbeda-beda antara satu daerah dengan daerah yang lainnya akan berdampak pada pertumbuhan ekonomi yang berbeda pula, sehingga mengakibatkan penurunan tingkat pengangguran dan tingkat kemiskinan yang tidak sama antara daerah satu dengan daerah lainnya. Idealnya Pendapatan Asli Daerah (PAD) menjadi sumber utama pendapatan daerah untuk membiayai anggaran daerah, karena kemampuan atau kontribusi Pendapatan Asli Daerah terhadap APBD akan menjadi tolak ukur pertumbuhan ekonomi daerah tersebut.

Peningkatan Pendapatan Asli Daerah (PAD) akan mendorong pertumbuhan ekonomi daerah. Adanya kenaikan Pendapatan Asli Daerah (PAD) akan memicu dan memacu pertumbuhan ekonomi daerah menjadi lebih baik dari pada pertumbuhan ekonomi daerah sebelumnya. Daerah yang pertumbuhan ekonominya positif mempunyai kemungkinan mendapatkan kenaikan PAD (Saragih, 2003).

Kenaikan Pendapatan Asli Daerah (PAD) juga dapat mengoptimalkan dan meningkatkan aktivitas pada sektor-sektor yang terkait dengan pertumbuhan ekonomi, seperti sektor industri dan perdagangan, sektor jasa, dan sektor-sektor lainnya. Jika terjadi Pendapatan Asli Daerah (PAD) berpengaruh pada pertumbuhan ekonomi. Maka terdapat kemungkinan kuat bahwa
Dana Alokasi Umum dan Dana Alokasi Khusus juga berpengaruh positif terhadap pertumbuhan ekonomi karena nilai Alokasi Umum dan Dana Alokasi khusus pada umumnya lebih besar dibandingkan kontribusi Pendapatan Asli Daerah.

Hasil penelitian Setiyawati dan Hamzah (2007) juga menemukan bahwa PAD berpengaruh positif terhadap pertumbuhan ekonomi sedangkan DAU berpengaruh negatif terhadap pertumbuhan ekonomi, untuk pengujian secara langsung pertumbuhan ekonomi terhadap kemiskinan menunjukkan adanya pengaruh yang signifikan tetapi pertumbuhan ekonomi berpengaruh negatif terhadap kemiskinan. Selanjutnya juga diketahui bahwa PAD, DAU dan DAK berpengaruh secara simultan terhadap pertumbuhan ekonomi, PAD, DAU dan DAK berpengaruh secara simultan terhadap kemiskinan, dan pertumbuhan ekonomi berpengaruh secara parsial terhadap kemiskinan.

Kemampuan pemerintah daerah dalam mengelola keuangan sendiri dituangkan dalam bentuk Anggaran Pendapatan Belanja Daerah (APBD) baik secara langsung, seperti halnya (Halim, 2007) mengatakan bahwa sumber dana tersebut tercantum dalam APBD yang mencakup transfer dana perimbangan dari pemerintah pusat, yang mana mencerminkan kemampuan pemerintah dalam kemandirian di masing-masing daerah dengan melihat dari segi pendapatan yaitu PAD, DAU, DAK dan Belanja Pembangunan. Oleh karena itu penilaian terhadap pertumbuhan ekonomi terhadap keberhasilan mengatasi kesenjangan kemiskinan di daerah dapat diminimumkan guna pemerataan pembangunan ekonomi.

Berdasar pada latar belakang masalah penelitian diatas maka penelitian ini bertujuan untuk mengetahui dan menganalisis : 1) pengaruh PAD terhadap pertumbuhan ekonomi, 2) pengaruh DAU terhadap pertumbuhan ekonomi. 3) pengaruh DAK terhadap pertumbuhan ekonomi, 4) pengaruh PAD terhadap kemiskinan, 5) pengaruh DAU terhadap kemiskinan. 6) pengaruh DAK terhadap kemiskinan, 7) pengaruh pertumbuhan ekonomi terhadap kemiskinan, 
8) pengaruh PAD terhadap kemiskinanmelalui pertumbuhan ekonomi sebagai variabel intervening. 9) Pengaruh DAU terhadap kemiskinan melalui pertumbuhan ekonomi sebagai variabel intervening, 10) Pengaruh DAK terhadap kemiskinan melalui pertumbuhan ekonomi sebagai variabel intervening.

\section{METODE PENELITIAN}

Penelitian ini menggunakan data sekunder maka langkah pertama peneliti akan mengumpulkan data berbentuk data data panel berupa selama 5 tahun terakhir yaitu tahun 2010 - 2014. Penelitian ini dilakukan pada Pemerintah Kabupaten/Kota di Provinsi Sumatera Barat yang berjumlah 19 Kabupaten/Kota di Provinsi Sumatera Barat.

Variabel terikat pada penelitian ini adalah kemiskinan (Y) adalah ketidakmampun seseorang untuk memenuhi kebutuhan makanan maupun non makanan yang bersifat mendasar. Data kemiskinan pada penelitian diukur dalam satuan orang atau jumlah penduduk yang masuk dalam garis kemiskinan semenjak tahun 2010-2014.

Variabel Intervening pada penelitian ini adalah pertumbuhan ekonomi (M) adalah perkembangan kegiatan dalam perekonomian Kabupaten/Kota di Provinsi Sumatera Barat yang menyebabkan barang dan jasa yang diproduksi dalam masyarakat bertambah dan kemakmuran masyarakat meningkat. Data pertumbuhan ekonomi pada penelitian diukur dengan menggunakan PDRB atas harga konstan.

Variabel Bebas (Independent Variabel) yaitu : 1) Pendapatan Asli Daerah (X1). Pendapatan Asli Daerah adalah total pendapatan daerah Kabupaten/Kota di Provinsi Sumatera Barat yang berasal Pajak Daerah, Retribusi Daerah, Pendapatan dari Laba Perusahaan Daerah dan lain-lain pendapatan. Data pendapatan asli daerah pada penelitian diukur dalam satuan rupiah. 2) Dana Alokasi Umum (X2). Dana Alokasi Umum adalah dana dari Perimbangan dari Pemerintah pusat ke Pemerintah Daerah Kabupaten/Kota di Provinsi Sumatera Barat untuk mengatasi ketimpangan horizontal dengan tujuan utama untuk pemerataan kemampuan keuangan antar daerah. Data Dana Alokasi Umum pada penelitian diukur dalam satuan rupiah. 3) Dana Alokasi Khusus (X3). Dana Alokasi Khusus adalah dana yang dialokasikan kepada daerah Kabupaten/Kota di Provinsi Sumatera Barat untuk membantu membiayai kebutuhan khusus. Data Dana Alokasi Khusus pada penelitian diukur dalam satuan rupiah.

\section{PEMBAHASAN}

\section{Analisis Deskriptif}

Pada bagian ini penulis akan menjelaskan secara deskriptif variabel penelitian. Statistik deskriptif dari data masing-masing variabel dapat dilihat pada tabel dibawah ini.

Tabel 2

\section{Uji Statistik Deskriptif (Juta Rupiah)}

\begin{tabular}{|c|c|c|c|c|c|c|}
\hline \multicolumn{7}{|c|}{ Statistics } \\
\hline & & PAD & DAU & DAK & Pdd. Mskin & P. Ekonomi \\
\hline $\mathrm{N}$ & Valid & 95 & 95 & 95 & 95 & 95 \\
\hline & Missing & 0 & 0 & 0 & 0 & 0 \\
\hline Mean & & 29290.3789 & 327919.2526 & 413712.6814 & 22773.4211 & 2088131.3645 \\
\hline Median & & 22176.0000 & 297522.0000 & 412917.8000 & 20400.0000 & 1289261.2500 \\
\hline Mode & & $20005.00^{\mathrm{a}}$ & $187600.00^{\mathrm{a}}$ & $116754.00^{\mathrm{a}}$ & $1300.00^{\mathrm{a}}$ & $373248.00^{\mathrm{a}}$ \\
\hline Std. Deviation & & 29194.6885 & 112785.67132 & 190851.50832 & 15479.229 & 2561799.09957 \\
\hline Variance & & 852329835 & 12720607654 & 36424298227 & 239606529 & 6562814626547 \\
\hline Range & & 194092.00 & 515516.00 & 853489.60 & 51967.00 & 13264261.41 \\
\hline Minimum & & 8873.00 & 187600.00 & 116754.00 & 1300.00 & 373248.00 \\
\hline Maximum & & 202965.00 & 703116.00 & 970243.60 & 53267.00 & 13637509.41 \\
\hline
\end{tabular}

Berdasarkan data pada Tabel 2 diketahui bahwa rata-rata PAD Kabupaten/Kota di Provinsi Sumatera Barat periode 2010-2014 adalah sebesar 29,29 Milyar dengan nilai tertinggi sebesar 202,96 Milyar dan nilai terendah sebesar 8,87 Milyar. Hal ini 
mengindikasikan masih adanya gap PAD antara beberapa daerah di Provinsi Sumatera Barat sehingga ada daerah yang memiliki PAD tinggi dan daerah yang memiliki PAD rendah.

Rata-rata DAU yang diterima Kabupaten/Kota di Provinsi Sumatera Barat setiap tahun selama periode 2010-2014 adalah sebesar 327,92 Milyar dengan nilai tertinggi sebesar 703,12 Milyar dan nilai terendah sebesar 187,6 Milyar. Hal ini mengindikasikan bahwa Kabupaten/Kota di Provinsi Sumatera Barat menerima DAU yang cukup tinggi setiap tahunnya.

Rata-rata DAK yang diterima Kabupaten/Kota di Provinsi Sumatera Barat setiap tahun selama periode 2010-2014 adalah sebesar 413,71 Milyar dengan nilai tertinggi sebesar 970,24 Milyar dan nilai terendah sebesar 116,75 Milyar. Hal ini mengindikasikan bahwa Kabupaten/Kota di Provinsi Sumatera Barat menerima DAK yang cukup tinggi setiap tahunnya.

Jumlah penduduk miskin di Kabupaten/Kota di Provinsi Sumatera Barat periode 2010-2014 adalah sebanyak 22.773 jiwa dengan nilai tertinggi sebesar 53.267 jiwa dan nilai terendah sebesar 1.300 jiwa. Data ini mengindikasikan bahwa jumlah penduduk miskin di Kabupaten/Kota Provinsi Sumatera Barat cukup tinggi setiap tahunnya.

Rata-rata tingkat pertumbuhan ekonomi di Kabupaten/Kota Provinsi Sumatera Barat periode 2010-2014 adalah sebanyak 2.088,13 Milyar dengan nilai tertinggi sebesar 13.637,51 Milyar dan nilai terendah sebesar 373.24 Milyar. Data ini mengindikasikan bahwa tingkat pertumbuhan ekonomi Kabupaten/Kota Provinsi Sumatera Barat setiap tahun belum tinggi.

\section{Uji Normalitas}

Pengujian terhadap normalitas data ini dilakukan untuk mengetahui apakah data mengikuti pola distribusi normal atau tidak. Model regresi yang baik adalah distribusi data normal atau mendekati normal. Berdasarkan hasil analisis data terhadap pengujian normalitas disajikan pada Tabel 3 di bawah ini:

Tabel 3

Uji Normalitas Data

One-Sample Kolmogorov-Smirnov Test

\begin{tabular}{|ll|r|}
\hline & & $\begin{array}{r}\text { Unstandardiz } \\
\text { ed Residual }\end{array}$ \\
\hline N & 95 \\
Normal Parameters & a,b & Mean \\
Most Extreme & Std. Dev iation & .0000000 \\
Diff erences & Absolute & 5990.743272 \\
& Positive & .084 \\
Kolmogorov-Smirnov Z & Negativ e & .084 \\
Asy mp. Sig. (2-tailed) & -.055 \\
\hline \multicolumn{2}{|c|}{ a. Test distribution is Normal. } \\
b. Calculated from data.
\end{tabular}

Sumber: Data Diolah, 2015

Berdasarkan tabel di atas terlihat semua variable residual memiliki nilai signifikansi sebesar 0,515 yaitu lebih besar dari alpha $(0,515>0,05)$. Dengan demikian dapat dikatakan bahwa data hasil penelitian sudah berdistribui normal sehingga analisis regresi dapat dilaksanakan.

\section{Uji Multikolinearitas}

Salah satu syarat untuk memakai analisis dengan menggunakan regresi linear berganda terlebih dahulu dilakukan uji multicolinearitas yaitu uji hubungan sesama variabel bebas.Analisis ini bertujuan untuk melihat korelasi sesama variabel bebas. Apabila terdapat korelasi yang tinggi sesama variabel bebas maka salah satu diantaranya dieleminir atau dikeluarkan dari model regresi berganda. 
Hasil uji multikolineritas data hasil ini. penelitian dapat dilihat pada Tabel 4 di bawah

Tabel 4

Hasil Uji Multikolinearitas

\begin{tabular}{|c|c|c|c|}
\hline \multicolumn{4}{|c|}{ Coeffi cients } \\
\hline \multirow{2}{*}{\multicolumn{2}{|c|}{ Model }} & \multicolumn{2}{|c|}{ Collinearity Statistics } \\
\hline & & Tolerance & VIF \\
\hline \multirow[t]{3}{*}{1} & PAD & .445 & 2.246 \\
\hline & DAU & .208 & 4.808 \\
\hline & DAK & .335 & 2.981 \\
\hline
\end{tabular}

a. Dependent Variable: Pdd. Miskin

Sumber : Olahan data sekunder, 2015

Berdasarkan hasil analisis data untuk uji multikolinearitas sebagaimana pada Tabel 5 di atas maka diketahui nilai tolerance masingmasing variabel bebas adalah PAD sebesar 0.445, DAU sebesar 0,208 dan DAk sebesar 0,335 sedangkan nilai VIF PAD adalah 2.246, DAU sebesar 4,808 dan DAK sebesar 2,981. Hal ini menunjukkan bahwa nilai VIF dari semua variabel bebas adalah lebih besar dari 10. Dengan demikian dapat dikatakan bahwa sesama variabel bebas tidak memiliki hubungan yang kuat satu sama lainnya. Dengan demikian dapat dikatakan bahwa data hasil penelitian ini tidak mengalami kasus multikolineritas, artinya bahwa sesama variabel bebas tidak berkorelasi kuat satu sama lainnya dapat dilakukan karena tidak terjadi multikolinearitas.

\section{Uji Heteroskedastisitas}

Uji Heterokedastisitas bertujuan untuk menguji apakah dalam sebuah model regresi terjadi ketidaksamaan varian dari residual suatu persamaan ke pengamatan lain. Jika varians dari residual dari satu pengamatan ke pengamatan lain tetap, maka disebut Homokedastisitas. Sedangkan jika varians berbeda, maka disebut heterokedastisitas. Sedangkan model regresi yang baik adalah jika tidak terjadinya heterokedastisitas. Untuk mendeteksi adanya heterokedastisitas dapat menggunakan uji Gletser. Hasil pengujian heteroskedastisitas dapat dilihat pada tabel 4 di bawah ini:

Tabel 5

Hasil Uji Heterokedastisitas

\begin{tabular}{clcc}
\hline No & \multicolumn{1}{c}{ Variabel } & Sig & Alpa \\
\hline 1 & Pendapatan Asli & 0,170 & 0,05 \\
& Daerah & 0,151 & 0,05 \\
2 & Dana Alokasi Umum & 0,05 \\
Dana Alokasi & 0,502 & \\
\hline Kumber: & Data Diolah, 2015
\end{tabular}

Dari Tabel 5 terlihat bahwa tidak terjadi heteroskedastisitas karena nilai signifikan dari semua variabel bebas lebih besar dari alpha $(0,05)$. Dengan demikian analisis regresi dapat dilakukan karena tidak terjadi heteroskedastisitas.

\section{Uji Autokorelasi}

Uji autokorelasi bertujuan menguji apakah dalam model regresi linier berganda ada korelasi antara kesalahan pengganggu pada periode t-1 (sebelumnya). Pengujian autokorelasi ini dengan menggunakan Durbin Watson dengan kriteria pengambilan keputusan jika nilai Durbin Watson antara -2 dan +2 maka tidak terjadi autokorelasi, 
adapun hasil uji autokorelasi dapat dilihat

pada pada tabel 6 berikut ini

Tabel 6

Hasil Uji Autokorelasi

\begin{tabular}{cc}
\hline Model & Durbin Watson \\
\hline 1 & 1.979 \\
\hline Sumber: Data Diolah, 2015 &
\end{tabular}

Dari hasil uji tabel 7 terlihat bahwa nilai Durbin Watson sebesar 1.948004. Nilai ini terletak antara -2 dengan +2 sehingga dapat dikatakan bahwa model regresi tidak mengandung autokorelasi.

\section{B. Pengujian Hipotesis}

1. Pengaruh PAD, DAU dan DAK terhadap PE

Untuk membuktikan pengaruh PAD, DAU dan DAK terhadap pertumbuhan ekonomi digunakan analisis regresi linear berganda. Hasil pengujiannya dapat dilihat pada tabel di bawah ini:

Tabel 7

Hasil Analisis Pengaruh PAD, DAU dan DAK terhadap PE

\begin{tabular}{|c|c|c|c|c|c|c|}
\hline No & Variabel & Notasi & $\begin{array}{c}\text { Koefisien } \\
\text { Regresi }\end{array}$ & $\begin{array}{c}\mathbf{t} \\
\text { hitung }\end{array}$ & Sig & Ket \\
\hline 1 & Konstanta & $\mathrm{a}$ & -2994877 & & & \\
\hline 2 & PAD & $\mathrm{X}_{1}$ & 50,468 & 15,460 & 0,000 & $\begin{array}{c}\mathrm{H}_{\mathrm{a}} \\
\text { Diterima }\end{array}$ \\
\hline 3 & DAU & $\mathrm{X}_{2}$ & 12,141 & 9,821 & 0,000 & $\begin{array}{c}\mathrm{H}_{\mathrm{a}} \\
\text { Diterima }\end{array}$ \\
\hline 4 & DAK & $X_{3}$ & $-0,910$ & $-1,581$ & 0,117 & $\begin{array}{c}\mathrm{H}_{\mathrm{a}} \\
\text { Ditolak }\end{array}$ \\
\hline \multicolumn{7}{|c|}{$\begin{array}{l}\text { R Square }=0,944 \\
\text { F Hitung }=510,749 \\
\text { F Prob. }=0,000\end{array}$} \\
\hline
\end{tabular}

Sumber: Data Diolah, 2015

Berdasarkan hasil analisis data, dapat dituliskan persamaan regresi linear berganda sebagai berikut:

$\mathrm{M}=\mathrm{a}+\mathrm{b}_{1} \mathrm{X}_{1}+\mathrm{b}_{2} \mathrm{X}_{2}+\mathrm{b}_{3} \mathrm{X}_{3}+\mathrm{e}$

$M=-2994877,02+50,468 X_{1}+12,141 X_{2}+0,910 X_{3}+e$

Selanjutnya berdasarkan hasil analisis data maka dilakukan pengujian hipotesis akan dijelaskan sebagai berikut:

1. Nilai konstanta sebesar $-2994877,02$ menunjukkan besarnya nilai variabel niali pertumbuhan ekonomi (PDRB atas harga konstan) tanpa dipengaruhi oleh PAD, DAU dan DAK. Apabila variabel PAD, DAU dan DAK bernilai nol maka nilai variabel pertumbuhan ekonomi sudah ada sebesar 2994877,02.

2. Nilai $F$ hitung adalah 510,749 dengan tingkat signifikansi sebesar 0,000 atau lebih kecil dari 0,05. Dengan demikian, dapat dikatakan bahwa model yang dihasilkan pada penelitian ini adakal predictor yang valid dalam memprediksi nilai variabel terikat.
3. Nilai $\mathrm{R}^{2}$ ( $R$ square) adalah 0,944 . Hal ini berarti besar pengaruh PAD, DAU dan DAK terhadap pertumbuhan ekonomi adalah $94,4 \%$. Sedangkan sisanya sebesar $5,6 \%$ dipengaruhi oleh variabel lain yang tidak termasuk dalam model penelitian ini.

4. Nilai koefisien regresi variabel $\operatorname{PAD}\left(\mathrm{X}_{1}\right)$ adalah 50,468 yang bertanda positif dengan nilai signifikansi sebesar 0,000. Nilai signifikansi lebih kecil dari alpha $(0,000<0,05)$. Dengan demikian, dapat diartikan bahwa PAD berpengaruh signifikan terhadap pertumbuhan ekonomi. Oleh karena itu hipotesis pertama yang menyatakan bahwa "PAD berpengaruh signifikan terhadap pertumbuhan ekonomi Kabupaten/Kota di Provinsi Sumatera Barat" diterima.

5. Nilai koefisien regresi variabel $\mathrm{DAU}\left(\mathrm{X}_{2}\right)$ adalah 12,141 yang bertanda positif dengan nilai signifikansi sebesar 0,000. 
Nilai signifikansi lebih kecil dari alpha $(0,000<0,05)$. Dengan demikian, dapat diartikan bahwa DAU berpengaruh signifikan terhadap pertumbuhan ekonomi. Oleh karena itu hipotesis kedua yang menyatakan bahwa "DAU berpengaruh signifikan terhadap pertumbuhan ekonomi Kabupaten/Kota di Provinsi Sumatera Barat" diterima

6. Nilai koefisien regresi variabel $\operatorname{DAK}\left(\mathrm{X}_{3}\right)$ adalah 0,910 yang bertanda negatif dengan nilai signifikansi sebesar 0,117. Nilai signifikansi lebih besar dari alpha $(0,117>0,05)$. Dengan demikian, dapat diartikan bahwa DAK tidak berpengaruh signifikan terhadap pertumbuhan ekonomi. Oleh karena itu hipotesis ketiga yang menyatakan bahwa "DAK berpengaruh signifikan terhadap pertumbuhan ekonomi Kabupaten/Kota di Provinsi Sumatera Barat" ditolak

\section{Pengaruh PAD, DAU dan DAK terhadap Kemiskinan}

Untuk membuktikan pengaruh PAD, DAU dan DAK terhadap kemiskinan digunakan analisis regresi linear berganda. Hasil pengujiannya dapat dilihat pada tabel di bawah ini:

Tabel 8

Hasil Analisis Pengaruh PAD, DAU dan DAK terhadap Kemiskinan

\begin{tabular}{llrrrrl}
\hline $\begin{array}{l}\text { N } \\
\text { o }\end{array}$ & Variabel & Notasi & $\begin{array}{c}\text { Koefisien } \\
\text { Regresi }\end{array}$ & \multicolumn{1}{c}{$\begin{array}{c}\text { t } \\
\text { hitung }\end{array}$} & Sig & Ket \\
\hline 1 & Konstanta & A & $-21319,663$ & & & \\
2 & PAD & X1 & $-0,173$ & $-5,375$ & 0,000 & $\mathrm{H}_{\mathrm{a}}$ Diterima \\
3 & DAU & $\mathrm{X} 2$ & $-0,145$ & - & 0,000 & $\mathrm{H}_{\mathrm{a}}$ Diterima \\
4 & DAK & $\mathrm{X} 3$ & 0,004 & 0,634 & 0,527 & $\mathrm{H}_{\mathrm{a}}$ Ditolak \\
\hline R Square $=0,850$ & & & & \\
$\begin{array}{l}\text { F Hitung }=172,182 \\
\text { F Prob. }=0,000\end{array}$ & & & & \\
\hline
\end{tabular}

Sumber: Data Diolah, 2015

Berdasarkan hasil analisis data, dapat dituliskan persamaan regresi linear berganda sebagai berikut:

$\mathrm{Y}=\mathrm{a}+\mathrm{b}_{1} \mathrm{X}_{1}+\mathrm{b}_{2} \mathrm{X}_{2}+\mathrm{b}_{3} \mathrm{X}_{3}+\mathrm{e}$

$\mathrm{Y}=-21319,663-0,173 \mathrm{X}_{1}-0,145 \mathrm{X}_{2}-$

$0,004 X_{3}+e$

Selanjutnya berdasarkan hasil analisis data maka dilakukan pengujian hipotesis akan dijelaskan sebagai berikut:

1. Nilai konstanta sebesar $-21319,663$ menunjukkan besarnya nilai variabel kemiskinan tanpa dipengaruhi oleh PAD, DAU dan DAK. Apabila variabel PAD, DAU dan DAK bernilai nol maka nilai variabel kemiskinan sudah ada sebesar 2994877,02.

2. Nilai $F$ hitung adalah 172,182 dengan tingkat signifikansi sebesar 0,000 atau lebih kecil dari 0,05. Dengan demikian, dapat dikatakan bahwa model yang dihasilkan pada penelitian ini adakal predictor yang valid dalam memprediksi nilai variabel terikat.
3. Nilai $\mathrm{R}^{2}$ ( $R$ square) adalah 0,850 . Hal ini berarti besar pengaruh PAD, DAU dan DAK terhadap kemiskinan adalah $85 \%$. Sedangkan sisanya sebesar $15 \%$ dipengaruhi oleh variabel lain yang tidak termasuk dalam model penelitian ini.

4. Nilai koefisien regresi variabel $\operatorname{PAD}\left(\mathrm{X}_{1}\right)$ adalah 0,173 yang bertanda negative dengan nilai signifikansi sebesar 0,000. Nilai signifikansi lebih kecil dari alpha $(0,000<0,05)$. Dengan demikian, dapat diartikan bahwa PAD berpengaruh signifikan terhadap kemiskinan. Oleh karena itu hipotesis keempat yang menyatakan bahwa "PAD berpengaruh signifikan terhadap kemiskinan Kabupaten/Kota di Provinsi Sumatera Barat" diterima.

5. Nilai koefisien regresi variabel $\operatorname{DAU}\left(\mathrm{X}_{2}\right)$ adalah 0,145 yang bertanda negative dengan nilai signifikansi sebesar 0,000. Nilai signifikansi lebih kecil dari alpha $(0,000<0,05)$. Dengan demikian, dapat 
diartikan bahwa DAU berpengaruh signifikan terhadap kemiskinan. Oleh karena itu hipotesis kelima yang menyatakan bahwa "DAU berpengaruh signifikan terhadap kemiskinan Kabupaten/Kota di Provinsi Sumatera Barat" diterima

6. Nilai koefisien regresi variabel $\operatorname{DAK}\left(\mathrm{X}_{3}\right)$ adalah 0,004 yang bertanda negatif dengan nilai signifikansi sebesar 0,527. Nilai signifikansi lebih besar dari alpha $(0,527>0,05)$. Dengan demikian, dapat diartikan bahwa DAK tidak berpengaruh signifikan terhadap kemiskinan. Oleh karena itu hipotesis keenam yang menyatakan bahwa "DAK berpengaruh signifikan terhadap pertumbuhan ekonomi Kabupaten/Kota di Provinsi Sumatera Barat" ditolak

\section{Pengaruh Pertumbuhan Ekonomi terhadap Kemiskinan \\ Untuk membuktikan pengaruh} pertumbuhan ekonomi terhadap kemiskinan digunakan analisis regresi linear sederhana. Hasil pengujiannya dapat dilihat pada tabel di bawah ini:

Tabel 9

Hasil Analisis Pengaruh PE terhadap Kemiskinan

\begin{tabular}{llrrrrr}
\hline $\begin{array}{l}\text { N } \\
\text { o }\end{array}$ & Variabel & Notasi & $\begin{array}{c}\text { Koefisien } \\
\text { Regresi }\end{array}$ & $\begin{array}{c}\mathbf{t} \\
\text { hitung }\end{array}$ & Sig & Ket \\
\hline 1 & Konstanta & a & $-14423,068$ & & & \\
2 & PE & M & $-0,004$ & $-8,514$ & 0,000 & $\begin{array}{c}\mathrm{H}_{\mathrm{a}} \\
\text { Diterima }\end{array}$ \\
\hline R Square $=0,438$ & & & & & \\
$\begin{array}{l}\text { F Hitung }=72,484 \\
\text { F Prob. }=0,000\end{array}$ & & & & & \\
\hline
\end{tabular}

Sumber: Data Diolah, 2015

Berdasarkan hasil analisis data, dapat dituliskan persamaan regresi linear berganda sebagai berikut:

$\mathrm{Y}=\mathrm{a}+\mathrm{bM}+\mathrm{e}$

$\mathrm{Y}=-14423,068+0,004 \mathrm{M}+\mathrm{e}$

Selanjutnya berdasarkan hasil analisis data maka dilakukan pengujian hipotesis akan dijelaskan sebagai berikut:

1. Nilai konstanta sebesar $-14423,068$ menunjukkan besarnya nilai variabel kemiskinan tanpa dipengaruhi oleh pertumbuhan ekonomi. Apabila variabel pertumbuhan ekonomi bernilai nol maka nilai variabel kemiskinan sudah ada sebesar $-14423,068$.

2. Nilai $F$ hitung adalah 72,484 dengan tingkat signifikansi sebesar 0,000 atau lebih kecil dari 0,05. Dengan demikian, dapat dikatakan bahwa model yang dihasilkan pada penelitian ini adakal predictor yang valid dalam memprediksi nilai variabel terikat.

3. Nilai $\mathrm{R}^{2}$ ( $R$ square) adalah 0,438 . Hal ini berarti besar pengaruh pertumbuhan ekonomi terhadap kemiskinan adalah $43,8 \%$. Sedangkan sisanya sebesar 52,6\% dipengaruhi oleh variabel lain yang tidak termasuk dalam model penelitian ini.

4. Nilai koefisien regresi variabel $\operatorname{PE}(\mathrm{M})$ adalah 0,004 yang bertanda negative dengan nilai signifikansi sebesar 0,000. Nilai signifikansi lebih kecil dari alpha $(0,000<0,05)$. Dengan demikian, dapat diartikan bahwa PE berpengaruh signifikan terhadap kemiskinan. Oleh karena itu hipotesis ketujuh yang menyatakan bahwa "pertumbuhan ekonomi berpengaruh signifikan terhadap kemiskinan Kabupaten/Kota di Provinsi Sumatera Barat" diterima.

\section{Pengaruh PAD, DAU dan DAK Terhadap Kemiskinan Melalui Pertumbuhan Ekonomi Sebagai Variabel Intervening}

Untuk melakukan pengujian pengaruh PAD, DAU dan DAK terhadap kemiskinan melalui pertumbuhan ekonomisebagai 
variabel intervening, digunakan analisa regresi variabel mediasi metode kausal step yang dikembangkan oleh Baron dan Kenny (1986). Menurut Barron dan Kenny (1986) terdapat 3 langkah dalam melakukan pengujian pengaruh variabel mediasi. Ketiga langkah tersebut adalah sebagai berikut:

1. Variabel bebas harus berpengaruh signifikan terhadap variabel mediasi ( $B 2$ harus signifikan).

2. Variabel bebas harus berpengaruh signifikan terhadap variabel terikat ( $ß 1$ harus signifikan).

3. Variabel mediasi harus berpengaruh signifikan terhadap variabel terikat (B3 harus signifikan).

Variabel M dinyatakan sebagai variabel mediasi sempurna (full mediation) jika setelah memasukan variabel $\mathrm{M}$, pengaruh $\mathrm{X}$ terhadap $\mathrm{Y}$ menurun menjadi nol atau yang tadinya signifikan (sebelum memasukan variabel $\mathbf{M}$ ) menjadi tidak signifikan setelah memasukan variabel $M$ ke dalam persamaan regresi. Variabel $\mathrm{M}$ dinyatakan sebagai variabel mediasi parsial (partial mediation) jika setelah memasukan variabel $\mathrm{M}$, pengaruh $\mathrm{X}$ terhadap $\mathrm{Y}$ yang tadinya signifikan (sebelum memasukan variabel M) menjadi tetap signifikan setelah memasukan variabel $\mathrm{M}$ ke dalam persamaan regresi, tetapi mengalami penurunan koefisien regresi.

Persyaratan pertama dalam menguji peran variabel intervening adalah variabel bebas harus berpengaruh signifikan terhadap variabel mediasi. Berdasarkan hasil data dalam menguji pengaruh variabel bebas terhadap variabel mediasi (langkah pertama), ditemukan bahwa PAD dan DAU berpengaruh signifikan terhadap pertumbuhan ekonomi sedangkan variabel DAK tidak berpengaruh signifikan. Dengan demikian, variabel DAK tidak memenuhi persyaratan pada langkah pertama dalam pengujian pengaruh mediasi.

Persyaratan pertama dalam menguji peran variabel intervening adalah variabel bebas harus berpengaruh signifikan terhadap variabel terikat. Berdasarkan hasil data dalam menguji pengaruh variabel bebas terhadap variabel terikat (langkah kedua), ditemukan bahwa PAD dan DAU berpengaruh signifikan terhadap kemiskinan sedangkan variabel DAK tidak berpengaruh signifikan. Dengan demikian, variabel DAK juga tidak memenuhi persyaratan pada langkah kedua dalam pengujian pengaruh mediasi.

Persyaratan ketiga dalam menguji peran variabel intervening adalah variabel mediasi harus berpengaruh signifikan terhadap variabel terikat. Berdasarkan hasil analisis data dengan regresi sederhana memperlihatkan bahwa variabel pertumbuhan ekonomi (M) berpengaruh signifikan terhadap kemiskinan. Dengan demikian persyaratan ketiga dalam pengujian pengaruh mediasi terpenuhi.

Berdasarkan hasil uji pada langkah pertama, kedua, dan ketiga, hanya variabel PAD $\left(X_{1}\right)$ dan DAU $\left(X_{3}\right)$ yang memenuhi persayaratan uji mediasi. Adapun hasil pengujian pengaruh variabel mediasi dengan regresi bertingkat dapat dilihat pada pada tabel berikut ini.

\section{Tabel 10}

Hasil Uji Regresi Variabel Mediasi

\begin{tabular}{|c|c|c|c|c|c|}
\hline \multirow[b]{2}{*}{$\begin{array}{l}\text { Variabel } \\
\text { Terikat }\end{array}$} & \multirow{2}{*}{$\begin{array}{c}\text { Variabel } \\
\text { Bebas dan } \\
\text { Mediasi }\end{array}$} & \multicolumn{2}{|c|}{ Tahap 1} & \multicolumn{2}{|c|}{ Tahap 2} \\
\hline & & $\begin{array}{c}\text { Koefisien } \\
\text { regresi }\end{array}$ & Sig. & $\begin{array}{c}\text { Koefisien } \\
\text { regresi }\end{array}$ & Sig. \\
\hline \multirow{6}{*}{$\begin{array}{l}\text { Kemiskinan } \\
\text { (Y) }\end{array}$} & Konstanta (a) & $-21575,006$ & 0,000 & -11860.835 & $-0,001$ \\
\hline & $\operatorname{PAD}\left(\mathrm{X}_{1}\right)$ & $-0,183$ & 0,000 & $-0,359$ & 0,000 \\
\hline & $\mathrm{DAU}\left(\mathrm{X}_{2}\right)$ & $-0,152$ & 0,000 & $-0,117$ & 0,000 \\
\hline & PE (M) & - & - & $-0,003$ & 0,001 \\
\hline & $\mathrm{R}^{2}$ & 0,850 & & 0,867 & \\
\hline & Perubahan $\mathrm{R}^{2}$ & & & 0,017 & \\
\hline
\end{tabular}

Sumber : Data Diolah, 2015 
Berdasarkan analisis data untuk pengujian pengaruh variabel mediasi dapat diketahui bahwa:

a. Uji Hipotesis Kedelapan

Berdasarkan hasil analisis data untuk pengujian hipotesis kedelapan diketahui bahwa :

1) PAD $\left(\mathrm{X}_{1}\right)$ berpengaruh signifikan terhadap pertumbuhan ekonomi (M) dimana nilai koefisien regesi adalah 50,468 dengan tingkat signifikansi adalah 0,000 (persyaratan pertama terpenuhi)

2) $\mathrm{PAD}\left(\mathrm{X}_{1}\right)$ berpengaruh signifikan terhadap kemiskinan (Y) dengan nilai koefisien regesi adalah $-0,173$ dengan tingkat signifikansi adalah 0,000 (persyaratan kedua terpenuhi)

3) Pertumbuhan ekonomi (M) berpengaruh signifikan terhadap kemiskinan (Y) dengan nilai koefisien regesi adalah 0,004 dengan tingkat signifikansi adalah 0,000 (persyaratan ketiga terpenuhi)

Dengan demikian, hipotesis kedelapan yang menyatakan "PAD berpengaruh signifikan terhadap kemiskinan melalui pertumbuhan ekonomi sebagai variabel intervening". diterima.

Setelah dimasukan variabel mediasi (M) ke dalam model penelitian maka diketahui pertumbuhan ekonomi berperan sebagai variabel mediasi parsial (partial mediation) karena PAD tadinya signifikan (sebelum memasukan variabel $\mathrm{M}$ ) menjadi tetap signifikan setelah memasukan variabel $\mathrm{M}$ ke dalam persamaan regresi, tetapi mengalami penurunan koefisien regresi dari $-0,183$ menjadi -0,359. Hal ini dapat diartikan bahwa pertumbuhan ekonomi memediasi secara parsial (partial mediation) hubungan antara PAD dengan kemiskinan.

b. Uji Hipotesis Kesembilan

Berdasarkan hasil analisis data untuk pengujian hipotesis kesembilan diketahui bahwa :

1) DAU $\left(X_{2}\right)$ berpengaruh signifikan terhadap pertumbuhan ekonomi (M) dimana nilai koefisien regesi adalah 12,141 dengan tingkat signifikansi adalah 0,000 (persyaratan pertama terpenuhi)

2) DAU $\left(X_{2}\right)$ berpengaruh signifikan terhadap kemiskinan (Y) dengan nilai koefisien regesi adalah $-0,145$ dengan tingkat signifikansi adalah 0,000 (persyaratan kedua terpenuhi)

3) Pertumbuhan ekonomi (M) berpengaruh signifikan terhadap kemiskinan (Y) dengan nilai koefisien regesi adalah 0,004 dengan tingkat signifikansi adalah 0,000 (persyaratan ketiga terpenuhi)

Dengan demikian, hipotesis kedelapan yang menyatakan "DAU berpengaruh signifikan terhadap kemiskinan melalui pertumbuhan ekonomi sebagai variabel intervening". diterima.

Setelah dimasukan variabel mediasi (M) ke dalam model penelitian maka diketahui pertumbuhan ekonomi berperan sebagai variabel mediasi parsial (partial mediation) karena DAU tadinya signifikan (sebelum memasukan variabel $\mathrm{M}$ ) menjadi tetap signifikan setelah memasukan variabel $\mathrm{M}$ ke dalam persamaan regresi, tetapi mengalami penurunan koefisien regresi dari -0,152 menjadi $-0,117$. Hal ini dapat diartikan bahwa pertumbuhan ekonomi memediasi secara parsial (partial mediation) hubungan antara DAU dengan kemiskinan.

c. Uji Hipotesis Kesepuluh

Berdasarkan hasil analisis data diketahui ditemukan bahwa variabel DAK tidak berpengaruh signifikan terhadap pertumbuhan ekonomi. Dengan demikian variabel DAK tidak memenuhi persyaratan uji variabel mediasi. Dengan demikian hipotesis kesepuluh (H10) yang menyatakan "DAK berpengaruh signifikan terhadap kemiskinan melalui pertumbuhan ekonomi sebagai variabel intervening" secara otomatis dinyatakan ditolak.

\section{Pembahasan Hasil Penelitian}

1. Pengaruh PAD terhadap Pertumbuhan Ekonomi

Berdasarkan pengujian hipotesis pertama diketahui PAD berpengaruh signifikan terhadap pertumbuhan ekonomi Kabupaten/Kota di Sumatera Barat. Apabila PAD mengalami peningkatan setiap tahunnya akan meningkatkan pertumbuhan ekonomi Kabupaten/Kota di Provinsi Sumatera Barat. Temuan penelitian ini membuktikan bahwa PAD berpengaruh signifikan terhadap 
pertumbuhan ekonomi Kabupaten/Kota di Provinsi Sumatera Barat disebabkan karena adanya peningkatan PAD Kabupaten/Kota setiap tahunnya akan meningkatkan pertumbuhan ekonomi.

Pendapatan Asli Daerah (PAD) menjadi sumber utama pendapatan daerah untuk membiayai anggaran daerah, karena kemampuan atau kontribusi Pendapatan Asli Daerah terhadap APBD akan menjadi tolak ukur pertumbuhan ekonomi daerah tersebut. Seharusnya dengan adanya peningkatan pendapatan asli daerah akan meningkatkan pertumbuhan ekonomi tetapi secara empiris temuan penelitian ini membuktikan bahwa peningkatan pendapatan asli daerah belum mampu meningkatkan pertumbuhan ekonomi Kabupaten/Kota di Provinsi Sumatera Barat yang dibuktikan oleh terjadinya peningkatan ketidakseimbangan antara peningkatan asli daerah dengan pertumbuhan ekonomi.

Dengan demikian dapat dikatakan bahwa salah satu bentuk penerimaan daerah adalah dalam bentuk Pendapatan Asli Daerah (PAD). Pada era otonomi daerah dimana sistem pemerintah masih berbentuk sentralisasi ternyata membawa dampak kurang baik pada pembangunan daerah. Hal ini terlihat dengan terhambatnya kebebasan daerah dalam mengembangkan segala potensi yang dimiliki oleh daerahnya dan dampak lainnya yang merugikan adalah tingginya tingkat ketergantungan pemerintah daerah terhadap pemerintah pusat. Hal ini disebabkan besarnya andil dan intervensi yang diberikan oleh pemerintah pusat terhadap jalannya pemerintahan di tiap daerah dan kini setelah otonomi daerah, sistem pemerintahan tidak lagi berupa sentralisasi tapi telah berubah menjadi desentralisasi. Artinya daerah telah memiliki kewenangan untuk mengembangkan segala potensi yang dimiliki oleh daerah tersebut. Dalam pelaksanaannya daerah harus lebih mandiri dalam mengelola berbagai bentuk penerimaan dan pengeluarannya. Untuk dapat menjalankan pemerintahannya pemerintah daerah diharapkan dapat mengoptimalkan pendapatan asli daerah.

Temuan penelitian ini konsisten dengan pendapat Saragih (2003) yang menyatakan bahwa peningkatan Pendapatan Asli Daerah
(PAD) akan mendorong pertumbuhan ekonomi daerah. Adanya kenaikan Pendapatan Asli Daerah (PAD) akan memicu dan memacu pertumbuhan ekonomi daerah menjadi lebih baik dari pada pertumbuhan ekonomi daerah sebelumnya. Selanjutnya Todaro (1998) secara spesifik menyebutkan ada tiga faktor atau komponen utama pertumbuhan ekonomi, yaitu akumulasi modal, pertumbuhan penduduk, dan hal-hal yang berhubungan dengan kenaikan jumlah angkatan kerja yang dianggap secara positif merangsang pertumbuhan ekonomi.

\section{Pengaruh DAU terhadap Pertumbuhan Ekonomi}

Berdasarkan pengujian hipotesis kedua diketahui DAU berpengaruh signifikan terhadap pertumbuhan ekonomi Kabupaten/Kota di Sumatera Barat. Apabila DAU mengalami peningkatan akan meningkatkan pertumbuhan ekonomi Kabupaten/Kota di Provinsi Sumatera Barat. Hal ini disebabkan karena dana transfer yang diterima oleh Kabupaten/Kota di Provinsi Sumatera Barat dengan optimal dipergunakan dalam meningkatkan kemampuan fiskal daerah sehingga dana alokasi umum tersebut mampu meningkatkan pertumbuhan ekonomi Kabupaten/Kota di Provinsi Sumatera Barat.

Alasan lainnya yang menyebabkan berpengaruhnya DAU terhadap pertumbuhan ekonomi adalah DAU dijadikan sebagai sumber pendanaan utama Pemda untuk membiayai operasi utamanya sehingga DAU tersebut dapat mengurangi kesenjangan fiskal antar daerah di Kabupaten/Kota di Provinsi Sumatera Barat yang pada gilirannya menunjang terhadap pertumbuhan ekonomi.

Dari temuan penelitian ini diketahui bahwa Dana alokasi umum merupakan jenis transfer dana antar tingkat pemerintahan yang tidak terikat dengan program pengeluaran tertentu. Dana alokasi umum ini dimaksudkan untuk menggantikan transfer berupa subsidi daerah otonom dan inpres. Adapun tujuan dari transfer ini adalah untuk menutup kesenjangan fiskal (fiscal gap) dan pemerataan kemampuan fiskal antara daerah antar daerah. Sehingga dana alokasi umum tiap daerah tidak akan sama besarnya. Daerah 
yang mempunyai pendapatan asli daerah rendah akan mendapatkan dana alokasi umum yang tinggi, dan begitu juga sebaliknya daerah yang mempunyai pendapatan asli daerah tinggi akan mendapatkan dana alokasi umum yang rendah.

Dana alokasi umum merupakan jenis transfer dana antar tingkat pemerintahan yang tidak terikat dengan program pengeluaran tertentu. Dana alokasi umum ini dimaksudkan untuk menggantikan transfer berupa subsidi daerah otonom dan inpres. Adapun tujuan dari transfer ini adalah untuk menutup kesenjangan fiskal (fiscal gap) dan pemerataan kemampuan fiskal antara daerah antar daerah. Sehingga dana alokasi umum tiap daerah tidak akan sama besarnya. Daerah yang mempunyai pendapatan asli daerah rendah akan mendapatkan dana alokasi umum yang tinggi, dan begitu juga sebaliknya daerah yang mempunyai pendapatan asli daerah tinggi akan mendapatkan dana alokasi umum yang rendah.

\section{Pengaruh DAK terhadap Pertumbuhan Ekonomi}

Berdasarkan pengujian hipotesis ketiga diketahui DAK berpengaruh signifikan terhadap pertumbuhan ekonomi Kabupaten/Kota di Sumatera Barat. Adanya peningkatan DAK setiap tahunnya dapat meningkatkan pertumbuhan ekonomi Kabupaten/Kota di Provinsi Sumatera Barat. Artinya semakin tinggi DAK Kabupaten/Kota di Provinsi Sumatera Barat dapat meningkatkan pertumbuhan ekonomi yang disebabkan karena penggunaan DAK sudah optimal dalam mendukung program-program pemerintah yang bertujuan untuk menggerakkan sektor-sektor perekonomian.

Selanjutnya diketahui bahwa DAK Kabupaten/Kota di Provinsi Sumatera Barat optimal digunakan untuk penanganan masalah-masalah seperti halnya mengurangi ketimpangan distribusi pendapatan, peningkatan penyediaan fasilitas dan kualitas kesehatan, peningkatan kualitas pendidikan, peningkatan kualitas lingkungan hidup dan belum optimal digunakan untuk penanganan masalah urban (daerah perkotaan)
Hasil penelitian ini relevan dengan Peraturan Pemerintah Nomor 104 tahun 2000, yang menyebutkan secara jelas mengenai tujuan dari penggunaan DAK, yang akibatnya tidak ada arahan yang jelas dalam penggunaannya baik itu untuk proyek-proyek prioritas nasional maupun proyek daerah.

Pertumbuhan ekonomi juga berkaitan dengan kenaikan "output perkapita". Dalam pengertian ini teori tersebut harus mencakup teori mengenai pertumbuhan GDP dan teori mengenai pertumbuhan penduduk. Sebab hanya apabila kedua aspek tersebut dijelaskan, maka perkembangan output perkapita bisa dijelaskan. Kemudian aspek yang ketiga adalah pertumbuhan ekonomi dalam perspektif jangka panjang, yaitu apabila selama jangka waktu yang cukup panjang tersebut output perkapita menunjukkan kecenderungan yang meningkat (Boediono, 1997).

\section{Pengaruh PAD terhadap Kemiskinan}

Berdasarkan pengujian hipotesis keempat diketahui PAD berpengaruh signifikan terhadap jumlah penduduk miskin Kabupaten/Kota di Sumatera Barat. Apabila PAD mengalami peningkatan akan dapat menurunkan jumlah penduduk miskin Kabupaten/Kota di Provinsi Sumatera Barat. Hal ini dapat diartikan bahwa apabila PAD mengalami peningkatan akan mampu mengurangi jumlah penduduk miskin karena PAD yang diterima sebahagian dapat digunakan untuk mendukung programprogram pengentasan kemiskinan sehingga dengan peningkatan jumlah PAD akan bisa menurunkan jumlah penduduk miskin.

Dari temuan penelitian ini diketahui bahwa melalui pemberlakuan desentralisasi fiskal, pemerintah daerah kini memiliki kewenangan yang besar untuk merencanakan, merumuskan, dan melaksanakan kebijakan serta program pembangunan yang bisa disesuaikan dengan kebutuhan setempat. Menurut McCulloch dan Suparnoko (2003), salah satu kunci yang harus diperhatikan dalam desentralisasi adalah bahwa pemerintah daerah harus lebih responsif terhadap kebutuhan penduduknya. Pada banyak negara berkembang termasuk Indonesia, tingkat 
kemiskinannya masih relatif tinggi dan oleh karenanya desentralisasi diharapkan akan menciptakan kebijakan-kebijakan yang lebih responsif terhadap kebutuhan penduduk miskin.

Dalam menelaah kebijakan pemerintah daerah dalam menanggulangi kemiskinan, perlu terlebih dahulu diperhatikan faktorfaktor penyebab kemiskinan atau dalam analisis kemiskinan disebut determinan kemiskinan. Kebijakan pemerintah daerah yang berorientasi pada program pengentasan kemiskinan sudah seharusnya didasarkan pada faktor-faktor yang mempengaruhi kondisi kemiskinan tersebut. Faktor-faktor penyebab kemiskinan dapat berupa karakteristik makro, sektor, komunitas, rumah tangga, dan individu (World Bank, 2002).

\section{Pengaruh DAU terhadap Kemiskinan}

Berdasarkan pengujian hipotesis kelima diketahui DAU berpengaruh signifikan terhadap jumlah penduduk miskin Kabupaten/Kota di Sumatera Barat. Apabila DAU mengalami peningkatan akan dapat menurunkan jumlah penduduk miskin pada Kabupaten/Kota di Provinsi Sumatera Barat.

Temuan penelitian ini membuktikan bahwa peningkatan DAU diterima oleh pemerintah daerah mampu menurunkan jumlah penduduk miskin pada Kabupaten/Kota di Provinsi Sumatera Barat karena program-program pengentasan kemiskinan yang dirancang oleh pemerintah daerah di Provinsi Sumatera Barat dibiayai dengan dana alokasi umum sehingga dengan adanya dana alokasi umum yang tinggi tentunya mendukung terhadap keberhasilan program pengenatasan kemiskinan.

World Bank (2002) mengkategorikan karakteristik penduduk miskin menurut komunitas, wilayah, rumah tangga, dan individu. Pada faktor komunitas, infrastruktur merupakan determinan utama kemiskinan. Keadaan infrastruktur sangat erat kaitannya dengan tingkat kesejahteraan masyarakat. Infrastruktur yang baik akan memudahkan masyarakat untuk melakukan aktivitas ekonomi maupun sosial kemasyarakatan, selain itu memudahkan investor untuk melakukan investasi di daerah yang bersangkutan. Indikator pembangunan infrastruktur yang penting adalah saluran irigasi, akses listrik, dan kondisi jalan utama transportasi. Indikator lain dari karakteristik faktor komunitas adalah akses yang sama terhadap usaha atau pekerjaan seperti keberadaan lembaga keuangan dan industri.

Pada tingkat wilayah ada bermacammacam karakteristik yang mungkin berkaitan dengan kemiskinan. Hubungan dari karakteristik tersebut dengan kemiskinan adalah sesuai dengan kondisi wilayah tersebut. Meskipun demikian, secara umum tingkat kemiskinan akan tinggi di wilayah dengan ciri-ciri sebagai berikut: terpencil secara geografis, sumberdaya yang rendah, curah hujan yang rendah, dan kondisi iklim yang tidak ramah.

\section{Pengaruh DAK terhadap Kemiskinan}

Berdasarkan pengujian hipotesis keenam diketahui DAU tidak berpengaruh signifikan terhadap jumlah penduduk miskin Kabupaten/Kota di Sumatera Barat. Apabila DAK mengalami peningkatan belum tentu dapat menurunkan jumlah penduduk miskin pada Kabupaten/Kota di Provinsi Sumatera Barat. Artinya adanya peningkatan DAK setiap tahun tidak dapat menekan jumlah penduduk miskin.

Temuan penelitian ini membuktikan bahwa DAK tidak berpengaruh signifikan terhadap kemiskinan. Artinya semakin tinggi DAK yang diterima oleh pemerintah daerah tidak dapat mengurangi jumlah penduduk miskin pada Kabupaten/Kota di Provinsi Sumatera Barat.

Dari hasil penelitian ini dapat dikatakan bahwa semakin tinggi DAK yang diusulkan oleh pemerintah daerah untuk program pengentasan kemiskinan belum dapat mengurangi jumlah penduduk miskin pada Kabupaten/Kota di Provinsi Sumatera Barat. Sehingga untuk masa yang akan datang diharapkan pemerintah daerah selalu mengusulkan lebih banyak program-program pengentasan kemiskinan kepada pemerintah pusat melalui dana alokasi khusus.

Aswadi dan Halim (2001) menyatakan bahwa tujuan dari penggunaan DAK dapat diarahkan pada upaya untuk meningkatkan 
Human Development Index atau Indeks Pembangunan Manusia yang merupakan salah satu isu nasional yang perlu dituntaskan.

\section{Pengaruh Pertumbuhan Ekonomi terhadap Kemiskinan}

Berdasarkan pengujian hipotesis ketujuh diketahui pertumbuhan ekonomi berpengaruh signifikan terhadap jumlah penduduk miskin Kabupaten/Kota di Sumatera Barat. Apabila pertumbuhan ekonomi mengalami peningkatan akan dapat menurunkan jumlah penduduk miskin pada Kabupaten/Kota di Provinsi Sumatera Barat.

Temuan penelitian ini membuktikan bahwa pertumbuhan ekonomi Kabupaten/Kota di Provinsi Sumatera Barat mampu menurunkan jumlah penduduk miskin karena pertumbuhan ekonomi bersangkutpaut dengan proses peningkatan produksi barang dan jasa dalam kegiatan ekonomi masyarakat, artinya semakin tinggi tingkat pertumbuhan produksi barang dan jasa dalam kegiatan ekonomi masyarakat di Kabupaten Kerinci tentunya akan menurunkan jumlah penduduk miskin.

Temuan penelitian ini konsisten dengan pendapat Wahyuni dan Siregar (2007) yang menyatakan bahwa pertumbuhan ekonomi merupakan syarat keharusan (necessary condition) bagi pengurangan kemiskinan. Adapun syarat kecukupannya (sufficient condition) adalah bahwa pertumbuhan tersebut efektif dalam mengurangi kemiskinn. Artinya, hendaklah menyebar si setiap golongan pendapatan, termasuk golongan penduduk miskin (growth with eaquility).

Kemampuan pemerintah daerah dalam mengelola keuangan sendiri dituangkan dalam bentuk Anggaran Pendapatan Belanja Daerah (APBD) baik secara langsung, Halim (2001) mengatakan bahwa sumber dana tersebut tercantum dalam APBD yang mencakup transfer dana perimbangan dari pemerintah pusat, yang mana mencerminkan kemampuan pemerintah dalam kemandirian di masing - masing daerah dengan melihat dari segi pendapatan yaitu PAD, DAU, DAK dan Belanja Pembangunan. Oleh karena itu penilaian terhadap pertumbuhan ekonomi terhadap keberhasilan mengatasi kesenjangan kemiskinan di daerah dapat diminimumkan guna pemerataan pembangunan ekonomi.

\section{Pengaruh PAD Terhadap Kemiskinan Melalui Pertumbuhan Ekonomi Sebagai Variabel Intervening}

Berdasarkan hasil pengujian hipotesis kedelapan diketahui PAD berpengaruh signifikan terhadap kemiskinan melalui pertumbuhan ekonomi sebagai variabel intervening. Hal ini berarti dengan adanya peningkatan pendapatan asli daerah dapat meningkatkan pertumbuhan ekonomi dan juga dapat menurunkan jumlah penduduk miskin sehingga pertumbuhan ekonomi berperan sebagai variabel intervening dari hubungan pendapatan asli darah dengan kemiskinan.

Temuan penelitian ini tidak konsisten dengan pendapat Suparnoko (2003) yang menyatakan bahwa salah satu kunci yang harus diperhatikan dalam desentralisasi adalah bahwa pemerintah daerah harus lebih responsif terhadap kebutuhan penduduknya. Pada banyak negara berkembang termasuk Indonesia, tingkat kemiskinannya masih relatif tinggi dan oleh karenanya desentralisasi diharapkan akan menciptakan kebijakan-kebijakan yang lebih responsif terhadap kebutuhan penduduk miskin.

Hasil penelitian ini tidak konsisten dengan penelitian terdahulu yang menemukan pendapatan asli daerah berpengaruh signifikan terhadap kemiskinan melaluipertumbuhan ekonomi sebagai variabel intervening (Nanga, 2006; Setiyawati dan Hamzah, 2007; Hamzah, 2007; Suryahadi, 2006; Asaddin dan Mansoer, 2001; Wahyuni dan Siregar, 2007)

\section{Pengaruh DAU Terhadap Kemiskinan Melalui Pertumbuhan Ekonomi Sebagai Variabel Intervening \\ Berdasarkan hasil pengujian hipotesis} kesembilan diketahui DAU berpengaruh signifikan terhadap kemiskinan melalui pertumbuhan ekonomi sebagai variabel intervening. Hal ini berarti dengan adanya peningkatan DAU dapat meningkatkan pertumbuhan ekonomi dan juga dapat menurunkan jumlah penduduk miskin 
sehingga pertumbuhan ekonomi berperan sebagai variabel intervening dari hubungan DAU dengan kemiskinan.

Dari temuan penelitian ini diketahui bahwa perbedaan DAU antara satu daerah dengan daerah yang lainnya berdampak pada pertumbuhan ekonomi yang berbeda pula, tetapi belum dapat menurunkan tingkat kemiskinan. Hal ini disebabkan karena DAU pada masing-masing Kabupaten/Kota di Provinsi Sumatera Barat belum mampu meningkatkan pertumbuhan ekonomi sehingga jumlah penduduk miskinpun tidak mengalami penurunan.

Hasil penelitian ini tidak konsisten dengan penelitian terdahulu yang menemukan pendapatan asli daerah berpengaruh signifikan terhadap kemiskinan melaluipertumbuhan ekonomi sebagai variabel intervening (Nanga, 2006; Setiyawati dan Hamzah, 2007; Hamzah, 2007; Suryahadi, 2006; Asaddin dan Mansoer, 2001; Wahyuni dan Siregar, 2007).

\section{Pengaruh DAK Terhadap Kemiskinan Melalui Pertumbuhan Ekonomi Sebagai Variabel Intervening}

Berdasarkan hasil pengujian hipotesis kesepuluh diketahui DAK tidak berpengaruh signifikan terhadap kemiskinan melalui pertumbuhan ekonomi sebagai variabel intervening. Hal ini berarti dengan adanya peningkatan DAK belum dapat menurunkan jumlah penduduk miskin melalui pertumbuhan ekonomi sehingga pertumbuhan ekonomi tidak berperan sebagai variabel intervening dari hubungan DAK dengan kemiskinan.

Dari temuan penelitian ini diketahui bahwa besarnya DAK yang diterima oleh Kabupaten/Kota tidak dapat meningkatkan pertumbuhan ekonomi, sehingga jumlah penduduk miskin tidak mengalami penurunan. Hal ini disebabkan oleh terjadinya pertumbuhan ekonomi tidak dipengaruhi oleh besar kecilnya DAK pada Kabupaten/Kota di Provinsi Sumatera Barat.

Dalam menelaah kebijakan pemerintah daerah dalam menanggulangi kemiskinan, perlu terlebih dahulu diperhatikan faktorfaktor penyebab kemiskinan atau dalam analisis kemiskinan disebut determinan kemiskinan. Kebijakan pemerintah daerah yang berorientasi pada program pengentasan kemiskinan sudah seharusnya didasarkan pada faktor-faktor yang mempengaruhi kondisi kemiskinan tersebut. Faktor-faktor penyebab kemiskinan dapat berupa karakteristik makro, sektor, komunitas, rumahtangga, dan individu (World Bank, 2002).

Hasil penelitian ini tidak konsisten dengan penelitian terdahulu yang menemukan DAK berpengaruh signifikan terhadap kemiskinan melaluipertumbuhan ekonomi sebagai variabel intervening (Nanga, 2006; Setiyawati dan Hamzah, 2007; Hamzah, 2007; Suryahadi, 2006; Asaddin dan Mansoer, 2001; Wahyuni dan Siregar, 2007).mengalami peningkatan setiap tahunnya akan meningkatkan pertumbuhan ekonomi Kabupaten/Kota di Provinsi Sumatera Barat.

\section{PENUTUP}

\section{Kesimpulan}

Berdasarkan analisis data dan pembahasan yang dikemukakan pada bab sebelumnya maka dapat diambil kesimpulan seperti yang diuraikan berikut ini:

1. Terdapat pengaruh yang signifikan PAD terhadap pertumbuhan ekonomi Kabupaten/Kota di Provinsi Sumatera Barat.

2. Terdapat pengaruh yang signifikan DAU terhadap pertumbuhan ekonomi Kabupaten/Kota di Provinsi Sumatera Barat.

3. Tidak terdapat pengaruh yang signifikan DAK terhadap pertumbuhan ekonomi Kabupaten/Kota di Provinsi Sumatera Barat.

4. Terdapat pengaruh yang signifikan PAD terhadap kemiskinan pada Kabupaten/Kota di Provinsi Sumatera Barat.

5. Terdapat pengaruh yang signifikan DAU terhadap kemiskinan pada Kabupaten/Kota di Provinsi Sumatera Barat.

6. Tidak terdapat pengaruh yang signifikan DAK terhadap kemiskinan pada 
Kabupaten/Kota di Provinsi Sumatera Barat.

7. Terdapat pengaruh yang signifikan pertumbuhan ekonomi terhadap kemiskinan pada Kabupaten/Kota di Provinsi Sumatera Barat.

8. Pendapatan asli daerah berpengaruh signifikan terhadap kemiskinan Kabupaten/Kota di Provinsi Sumatera Barat melaluipertumbuhan ekonomi sebagai variabel intervening.

9. DAU berpengaruh signifikan terhadap kemiskinan Kabupaten/Kota di Provinsi Sumatera Barat melaluipertumbuhan ekonomi sebagai variabel intervening.

10.DAK tidak berpengaruh signifikan terhadap kemiskinan Kabupaten/Kota di Provinsi Sumatera Barat melaluipertumbuhan ekonomi sebagai variabel intervening.

\section{Saran}

Adapun beberapa saran yang dapat penulis dampaikan berdasarkan hasil penelitian ini adalah sebagai berikut:

1. Akademis,

Hasil penelitian ini diharapkan dapat menjadi referensi bagi pembaca yang ingin mempelajari hal-hal yang berkaitan dengan pertumbuhan ekonomi dan kemiskinan dan untuk menambah wawasan penulis tentang variabel yang diteliti. Untuk peneliti berikutnya yang berminat untuk melakukan penelitian mengenai pertumbuhan ekonomi dan kemiskinan agar menambah variabel lain yang mempengaruhi variabel tersebut

2. Praktis

Hasil penelitian ini diharapkan dapat menjadi bahan pertimbangan bagi pemerintah Kabupaten/Kota se Provinsi Sumatera Barat untuk melakukan berbagai upaya agar memiliki kinerja keuangan yang lebih baik sehingga terwujud pemerintahan daerah yang otonom dan mempunyai kemampuan yang kuat dalam membiayai semua kebutuhannya, dan dalam meningkatkan kinerja keuangan pemerintahan Kabupaten/Kota di Provinsi Sumatera Barat, maka perlu diupayakan peningkatan kemampuan aparatur pemerintahan sehingga mampu memainkan peran sebagai pemikir, perencana, pelaksana, dan agent of change bagi kesuksesan pembangunan di Kabupaten/Kota di Provinsi Sumatera Barat dengan implikasi sebagai berikut :

a. Untuk meningkatkan tingkat kemandirian, Pemerintah Daerah Kabupaten/Kota di Provinsi Sumatera Barat diharapkan dapat mengoptimalkan Pendapatan Asli Daerah melalui sektor pajak dan retribusi yang berpotensi dan belum dimanfaatkan sepenuhnya oleh pemerintah daerah serta lebih meningkatkan Penerimaan Pendapatan Asli Daerah yang bersumber dari bagian laba badan usaha daerah.

b. Pemerintah Daerah Kabupaten/Kota di Provinsi Sumatera Barat sebaiknya menunjukkan biaya pemungutan Pendapatan Asli Daerah secara spesifik, yaitu dengan cara memberi penjelasan mengenai biaya-biaya yang dikeluarkan untuk memungut Pendapatan Asli Daerah sehingga tidak menyulitkan bagi orang yang ingin melakukan penelitian mengenai efisiensi keuangan daerah sekaligus melakukan evaluasi terhadap ukuran efisiensi

c. Pemerintah Daerah Kabupaten/Kota di Provinsi Sumatera Barat sebaiknya meningkatkan target Pendapatan Anggaran Daerah (PAD) dengan cara melakukan pemetaan terhadap potensi sumber-sumber penerimaan yang potensial.

3. Akademis,

Hasil penelitian ini diharapkan dapat menjadi referensi bagi pembaca yang ingin mempelajari hal-hal yang berkaitan dengan pertumbuhan ekonomi dan kemiskinan dan untuk menambah wawasan penulis tentang variabel yang diteliti

4. Peneliti berikutnya,

Untuk peneliti berikutnya yang berminat untuk melakukan penelitian mengenai 
pertumbuhan ekonomi dan kemiskinan agar menambah variabel lain yang mempengaruhi variabel tersebut

\section{DAFTAR PUSTAKA}

\subsection{2/economica.2016.v4.i2.633}

Arsyad, Lincolin. 1999. Pengantar Perencanaan dan Pembangunan Ekonomi Daerah. Edisi Pertama. Yogyakarta : BPFE

Bastian, Indra, 2006, Akuntansi Sektor Publik: Suatu Pengantar, Erlangga, Jakarta.

Boediono. 1997. Teori Pertumbuhan Ekonomi. Yogyakarta : BPFE.

Bratakusuma dan Sholikin. 2003. Perencanaan Pembangunan Daerah. Jakarta : Gramedia Pustaka Utama

Ghozali, Imam. 2011. ModelPersamaan: Konsep dan Aplikasi Dengan ProgramAMOS19. Jakarta: Erlangga

Gujarati, Damodar. 2003. Ekonometrika Dasar : Edisi Keenam. Jakarta: Erlangga.

Halim, Abdul. 2007. Akuntansi Keuangan Daerah. Jakarta. Salemba Empat

$$
\text { 2004. Bunga Rampai }
$$

Manajemen Keuangan Daerah, Yogyakarta : Unit Penerbitan dan Percetakan (UPM) AMP YKPN.

Jhingan. 2000. Ekonomi Pembangunan dan Perencanaan. Jakarta. Rajawali Press.

Kuncoro, Mudrajat. 2004. Otonomi dan Pembangunan Daerah : Reformasi, Perencanaan, Strategi dan Peluang. Jakarta : Erlangga.

Saragih, Juli Panglima. 2003. desentralisasi Fiskal dan Keuangan Daerah dalam Otonomi. Jakarta :Ghalia Indonesia.

Setiyawati, Anis dan Hamzah, Ardi. 2007. Analisa Pengaruh PAD, DAU, DAK dan Belanja Pembangunan Terhadap Pertumbuhan Ekonomi dan Kemiskinan : Pendekatan Analisis Jalur. The 1st Accounting Conference, Jakarta

Sidik, Machfud., Hidayanto, Djoko., Ismail, Tjip., Kadjatmiko., Pakpahan, Arlen Tobana., Adriansyah, 2004, Bunga Rampai Desentralisasi Fiskal, Direktorat Jenderal Perimbangan Keuangan Pusat dan Daerah, Jakarta
Sukirno, Sadono, 2012. Pengantar Teori Ekonomi Makro. Edisi ke 3. Jakarta:Raja Grafindo Persada

Suliyanto. 2011. Ekonometrika Terapan: Teori dan Aplikasi. Yogyakarta : Andi

Todaro M.P. 2006. Pembangunan Ekonomi di Dunia Ketiga, Jakarta :Erlangga

World Bank Institute. 2002. Dasar-dasar Analisis Kemiskinan. Edisi Terjemahan. Badan Pusat Statistik, Jakart 